\title{
Determinants of Demand for Fertiliser: A Conceptual Review
}

\author{
Abubakar Hamid Danlami \\ Department of Economics, Bayero University Kano, Nigeria
}

\begin{abstract}
It is generally agreed that optimum application of fertiliser at farm level have the tendency of improving soil fertility leading to the rise in agricultural production. Indeed one-third of the increase in cereal production worldwide has been attributed to fertiliser related factors. This paper reviews and synthesises various literature and empirical studies on fertiliser demand. The paper has shown that different models have been used by previous studies in analysing determinants of fertiliser demand or adoption, depending on the objective of a particular study. The paper also, has shown that differences in the areas under previous studies have led to differences in conclusions, mainly because of the variations of the socio-economic, geographical, environmental and other climatic factors. The paper conclude that there is a need for more studies on fertiliser demand each study to concentrate its analysis on a specific area or community so as to come up with suggestions and policies suitable for each community in order to improve fertiliser use by farmers so as to raise the level of agricultural productivity in developing countries.
\end{abstract}

\section{Introduction}

Fertiliser is known to be a powerful productivity enhancing input. Indeed one-third of the increase in cereal production worldwide has been attributed to fertiliser related factors FAO (1999). In the same vein, Anderson (1976), argue that "fertilisers contributed $55-57 \%$ of the rise in average yield per hectare" (as cited in FAO, 1999, p. 15). Also, practical experiences have shown that chemical fertilizer is one of the most reliable productivity enhancing inputs available to farmers (Ezeh, Onwuka, \& Nwachuku, 2006). However despite the vital role plays by fertiliser in agricultural production, farmers in Sub-Saharan Africa (SSA) still lag behind other areas in terms of fertiliser use compares to the recommended level.

For instance, in Nigeria, fertiliser recommendations based on the soil fertility is $142 \mathrm{~kg} / \mathrm{ha}$ of urea and $320 \mathrm{~kg} / \mathrm{ha}$ of blended NPK (20-10-10) for low fertile soil (Adeoye, 2006). However, the rate of fertiliser application in Nigeria is as low as $9 \mathrm{~kg} / \mathrm{ha}$ (Momoh, 2011). Lack of fertiliser means low yield which means low income, which in turn further keeps fertiliser economically out of reach of local farmers. These concerns highlight the need for a better understanding of the factors that influence farm holders` demand for fertiliser. Because as there is a strong correlation between crop yield and the volume of fertiliser utilisation, so there is a relationship between the fertiliser consumption of the farmer and selected socio-economic indicators. This condition motivates the need to analyse and assess the factors that influence small farm holders' fertiliser demand in rural areas, understanding the relative importance of various factors that influence fertiliser purchasing pattern contributes to the ability to take appropriate decisions as well as policy design that will stimulate fertiliser demand. As Kaburu (2002) ague; analysing micro level determinants of fertiliser use can improve the rate of fertiliser application by farmers at farm level use.

Though, there are a number of studies in this area, some of these studies are restricted to some categories of farmers. For instance, Kaburu (2002); Achieng, Friesen, Odongo, and Odendo (2001); Otunaiya and Akinleye (2003); Jayne, Xu, Black, and Goverch, (2005); and Paudel, Kumar and Matsuoka, (2009); concentrate their studies only on maize farmers. Furthermore, only few of the studies (e.g Dramadri, Hyuha \& Mugisha, 2005) in this area concentrated in a specific rural area, but most of the studies are macro in their approach covering wider areas such as a region, a country, or a continent as a whole mostly containing a heterogeneous different number of communities which produce findings that cannot be generalised to a specific single homogeneous community.

Furthermore, despite that most of the studies try to assess and examine the factors that affect fertiliser use, the findings, results and conclusions of these studies differ in most cases signifying that the results and findings from one area cannot be generalised to another area because the demand schedules for fertiliser differ within a region due to factors such as cultural practices, climate, soil type and fertility, nature of the crop grown, the farm structure as well as the general level of farmers' civilisation.

The main objective of this paper is to make a critical conceptual analysis of the determinants of fertiliser use and consumption in order to provide information on current understanding of the pattern of farmers fertiliser consumption behaviour in developing countries. 


\section{Literature Review And Empirical Frameworks}

The term fertiliser as defined in the national fertiliser policy document (NFPD, n.d.) means any substance containing one or more recognised plant nutrient(s) that is used for its plant nutrient content and is designed for use or claimed to have value in promoting plant growth. Forth (1984), defines fertiliser in broad sense as "all those organic and inorganic materials that are added to the soil to provide elements essential for growth of plants" (as cited in Fayaz, Jan, Jan, \& Ali, 2008, p. 1). Basically, fertiliser is categorised into two namely: organic fertiliser and inorganic fertiliser. According to NFPD (n.d) organic fertiliser means fertiliser derived from non-synthetic organic material, including sewage sludge, animal manures and plant residues produced through the process of drying, cooking, composting, chopping, grinding, fermenting or other methods and makes a declaration of nutrient value on the level. On the other hand, inorganic or mineral fertiliser means fertiliser produced by mineral processes or mined and derived from substance.

Such inorganic fertiliser is usually demanded by farmers not for direct consumption but for the purpose of producing agricultural products, therefore fertiliser demand is a drive demand in nature. This fertiliser demand as defined by Kelly (2001), means the quantity of fertiliser that farmers would be willing to purchase if it were available. It is the amount of fertiliser where by farmers are willing and able to buy at the prevailing price over a period of time. The quantity of fertiliser to be demanded by a particular farmer may be influenced by so many factors such as: the price of fertiliser, the farmer's income, profit from farming, the level of education of the farmer, availability of substitutes, the number of labour use on farms and the cost of the labour, the house hold size of the farmer, the farmer's experience in farming, the size of farm to be cultivated, as well as the farmers' contact with agricultural extension service officers.

Similarly, the demand for fertilizer as a factor of production in agriculture has been the focus of many studies over the years. The early studies include works by Griliches (1958); Heady and Yeh (1959); Carman (1979), and Okoroafor, Echebiri and Nwachukwu (2010). These studies use time series data to estimate determinants of demand for fertiliser in different areas and to assess the various elasticities of fertiliser demand. The major findings were that price elasticities of fertiliser demand was inelastic both for the short run and the long run. However these studies are macro based studies they lack disaggregated and specific analysis that may reflect the actual variants features of farmers in different locations and mostly the variables use are limited to various price, income and cross elasticities of fertiliser demand only.

Moreover, many studies use Logit regression model to evaluate determinants of fertiliser use (or demand) by farmers using cross - sectional data, with similar dependant variable which is 'fertiliser adoption' but with different independent variables. For instance Kaburu (2002) conducts a study that seeks to identify the major constraints for fertiliser use as perceived by farmers, assess the impact of these factors on fertiliser use. From the logit estimates and marginal analysis, education level and credit access shows to be most significant factors in determining fertiliser use at farm level. However the major limitation of this study is that most of the variables used in the model were found to be statistically in- significant including the price of fertiliser which was found to be not only insignificant but also positively related to fertiliser purchase, which is contrary to the established theory of demand.

On the contrary, a study by Olwande, Sikei and Mathenged (2009) shows that age, education, credit, presence of a cash crop, distance to fertiliser market and agro ecological potentials are statistically significant in influencing the probability of adopting fertiliser. The strongest determinants of fertiliser use intensity are gender, dependency ratio, credit, presence of cash crop, distance to extension service and agro ecological potential. Also, Olayide, Alene and Ikpi (2009) conduct a study on the determinants of fertiliser use in northern Nigeria, the variables measured include: distance of village to tarred road $(\mathrm{km})$, age of farmer, years of formal education, household size, and total land area cropped among others. The results show that the intensity of fertiliser use increases with family labour and physical access to fertiliser, but declines with cultivated land and plot distance from homestead. However both of these two studies (i.e Olwande et al., 2009 and Olayide et al., 2009) failed to examine the impact of price as one of the factors influencing fertiliser adoption. On the other hand, Paudel, Kumar and Matsuoka (2009) use Tobit regression model to identify the influence of socioeconomic factors of the improved maize adopters on the decision to adopt fertilizers in the Chitwan district of Nepal, the result shows that family size, farm size, credit use, off-farm income and irrigation availability, have positive influence on use of fertilizer in maize production.

Similarly, Fakoya and Mato (2003) conduct a study that examines the factors affecting the use of inorganic fertilisers in Zinder state of Niger republic. The study reveals that poor fertiliser distribution mechanism, inadequate supply and high transportation cost were the main factors associated with the use of fertiliser in the study area. The main constraints to the use of inorganic fertiliser in the area include: lack of credit facilities, high price of fertiliser, inadequate supply of fertiliser at the right time and lack of adequate knowledge on fertiliser application. The study shows that some independent variables such as: farm size, level of education, lack of credit and farming experience were significantly related to the use of inorganic fertilisers. As a limitation, this study also fails to examine the impact of fertiliser cost on farmers' decision to use fertiliser. 
Furthermore, there are some studies that examined factors affecting demand for fertiliser using OLS regression as the tools of analysis (Dramadri et al., 2005; Ebong \& Ebong, 2006; Ezeh et al., 2006 and Akpan \& Aya, 2009), in this case the dependent variable analysed is the quantity of fertiliser consumed. For instance study by Dramadri et al (2005) finds that input market access, farmers' experience in fertiliser use, formal education of farmer, extension services received, household income, group membership and farming labour were the factors that significantly influence demand for fertiliser. This study could have been one of the good studies on fertiliser demand had it include price of fertiliser in the model. In fact that is why the value of the coefficient of determination of the result is weak (0.46), signifying that there is a need to modify the model to include more important variables.

In line with Dramadri et al (2005), Ezeh et al (2006) finds that farmer incomes, farm experiences and transportation costs have significant impact statistically on quantity of fertiliser demand. However this study is superior to that of Dramadri et al (2005) in the sense that it included cost of fertiliser as one of the explanatory variables and it was found by the study to have statistical significant impact on quantity of fertiliser demand. The major limitation of this study is that it found that farm size and the number of contact with extension agent do not have significant impacts on quantity of fertiliser to be demanded by a farmer, the conclusion which is questionable.

Using the same model (OLS regression), Ebong and Ebong (2006) undertake a study which examines the demand for fertiliser technology by the smallholder crop farmers for sustainable agricultural development in Akwa Ibom state, Nigeria. The result indicates that farm size, price of fertiliser, price of manure and farmers education to be important variables that significantly affect the demand for fertiliser in the state. The major limitation of the model is that it fails to take into account the impact of some important variables such as: quantity of manure consumed, farming experience, number of contact with extension agents, family size, price of the output and the number of labour use on fertiliser demand. Also, the conclusion of the study that neither personal income of the farmer nor amount of loan obtained have significant impacts on fertiliser consumption is disputable.

As can be seen from the review of the previous studies on determinants of fertiliser demand, most of these studies generally concentrate on how factors such as price of fertiliser, income of the farmer, cost of transporting the fertiliser, farmer's level of education, years of experience in farming, household sizes and price of manure, influence the adoption or the quantity of fertiliser consumption with almost no attention given to how the farmers' expectations on produce price influences the quantity of fertiliser to be consumed. Similarly some of the studies are restricted to a particular group of farmers such as; maize producers, (Kaburu, 2000; Achienget al., 2001; Otunaiya \& Akinleye, 2003; Jayne et al., 2005; and Paudel et al., 2009), in which their findings and conclusions cannot be generalised to all farmers.

Furthermore, there exist inconsistencies among the findings of the previous studies. In most cases a variable appear to be statistically significant in one study, the same variable appear to be statistically insignificant in another study. For instance, variables such as; credit obtained, farm income, farm size, and number of meeting with extension agents were found to be statistically significant by Paudel et al. (2009) and Dramadri et al. (2005). The same variables were found to be statistically insignificant by Ezeh et al. (2006). Similarly, Ebong and Ebong (2006) found that personal income of the farmer is not significant in determining quantity of fertiliser consumption, while, Dramadri et al. (2005) conclude that it is among the significant determinants of fertiliser use. Olwande et al. (2009), found the level of formal education to be among significant factors that influence fertiliser adoption, while Paudel et al. (2009) found otherwise.

These differences in findings and conclusions may be due to differences in climate, soil type, crops grown and farm structure and for farmers with different socio-economic situations, signifying that the results and findings from one area cannot be generalised to another area, because the demand schedules for fertiliser differ within a region due to factors like cultural practices, climate, soil type and fertility, nature of the crops grown, the farming structure as well as the general level of farmers' knowledge and civilisation.

\section{Conclusion}

This paper reviews the various empirical studies on determinants of demand for fertiliser by farmers. These empirical studies can be categorised into two major groups based on their methodology (econometric tools of data analysis). The first category are those studies that use Logit Regression Model as their tool of analysis to assess the factors that influence fertiliser adoption by farmers, in this case, the sample group may consist of both farmers that use inorganic fertiliser and those that do not. On the other hand, the second category are those studies that examine determinants of quantity of fertiliser demand using Ordinary Least Square regression model as the tool of analysis, in this case the samples consist of only fertiliser users.

Furthermore, it was shown that the various studies vary in terms of number of variables used in their respective models depending majorly on the researchers' a priori knowledge. However, in some cases variables do overlap in different studies but mostly with different conclusions. This normally stems from the fact that such 
studies use different case study areas. This is because the socio - economic situations of farmers within a region differs due to factors such as cultural practices, climate differences, soil type and fertility, nature of the crops grown, the farming structure as well as the general level of farmers' civilisations and awareness. All these may lead to the differences in results and findings.

Therefore what is important is that there is need for more studies on the determinants of fertiliser demand each concentrating in a specific local community so as to come up with the results that actually reflect the situation of each community in order to design a policy that is relevant and suitable to each community. The overall target is raising agricultural yield by making efficient use of farm inputs.

\section{References}

[1]. Achieng, J., Friesen D., Odongo O., \& Odendo M. (April, 2001). Sustainability of fertiliser use on Maize Production in Western Kenya through Provision of Credit. Paper presented at the Eastern and South Africa Regional Maize Conference, Kenya.

[2]. Adeoye, G.O. (2006). Nutrients Rationalisation in Nigerian Compound (NPK) Fertilisers with Special Focus on Phosphorous and Potassium Utilisation USAID Research Report

[3]. Akpan, S.B., \& Aya, A.E. (2009). Determinants of Fertiliser use among Small-Holder Farmers in Wetland Region of Cross River State. Global Journal of Agricultural Sciences, 8(2) 195-201

[4]. Carman, H.F. (1979). The Demand for Nitrogen, Phosphorus and Potash Fertilizer Nutrients in the Western United States. Western Journal of Agricultural Economics, 4(0) 23-31.

[5]. Dramadri, J., Hyuha, T.S., \& Mugisha, J. (2005). Determinants of Demand for Purchased Fertilisers in Mbale District in Uganda. African Crop Science Conference Proceedings .7(771-774)

[6]. Ebong, V.O., \& Ebong, M.V. (2006). Demand for Fertiliser Technology by Smallholder Crop Farmers for Sustainable Agricultural Development in Akwa Ibom State, Nigeria. International journal of Agriculture \& Biology 1560-8530/2006/08-06-728-731 Retrieved July 16, 2011 from http://www.fspublishers.org

[7]. Ezeh, C.I., Onwuka, O.W., \& Nwachuku, I.N. (2006). Correlates of Inorganic Fertiliser Consumption among Smallholder Farmers in Abia State, Nigeria. Journal of Agriculture and Social Research8(1) Retrieved April 3, 2012 from http/www.ajol.info/index.php

[8]. Fakoya, E.O., \& Mato, Y. (2003). Factors Affecting the Use of Inorganic Based Fertilisers by Farmers in Zinder State of Niger Republic SET Series A(2003) 3(1),7-13.

[9]. Fayaz, M., Jan, D., Jan, A.U., \& Ali, G. (2008). Fertiliser Consumption by Farm Size in District Swabi. Sarhad Journal of Agric 24(1)198-201.

[10]. Federal Fertiliser Department of the Federal Ministry of Agriculture and Rural Development (n.d). National Fertiliser Policy for Nigeria Retrieved July 15, 2011 from http:// soilsnigeria.net/publications

[11]. Food and Agricultural Organisation (1999). Fertiliser Strategies. Retrieved August 1, 2011 from http://www.fertiliser.org

[12]. Griliches, Z. (1958). The Demand for Fertiliser: An Economic Interpretation of a Technical Change, Journal of Farm Economics, 40(3)

[13]. Heady, E.O., \& Yeh, M.H. (1959). National and Regional Demand Function for Fertiliser Journal of Farm Economics 41(2)

[14]. Jayne, T.S., Xu, Z., Black, J.R., \& Goverch, J. (July, 2005). Profitability of Fertiliser Use on Maize by Small-Scale Farming Households in Zambia. A Paper Presented at the American Agricultural Economics Association Annual Meeting, Rhode Island.

[15]. Kaburu, P.K. (2002). Determinants of Fertiliser Use at Farm Level: A Case Study of Small-Scale Farmers in Nakuru District Retrieved July 18, 2011 from http://www.kari.org/fileadmin/publicatios/10thproceedings/poster

[16]. Kelly, V.A., Mpyisi, E., Murekezi, A., \& Neven, D. (2001). Fertiliser Consumption in Rwanda. A Paper Prepared for the Policy Workshop on Fertiliser use and Marketing, 2001. Retrieved July 16, 2011 from http://aec.msu.edu/ $/$ rwanda

[17]. Momoh, S. (2011). Addressing the Nation`s Fertiliser Challenges.Retrieved July 15, 2011from http:// www.businessdayonline.com/NG/index.php/analysis

[18]. Okoroafor, O.N., Echebiri, R.N., \& Nwachukwu, I.N. (2010). Demand forFertiliser in Nigeria: An Application of Cointegration and Error Correction Modelling. Journal of Agriculture and Social Research 10(2) $142-152$

[19]. Olayide, O.E., Alene, A.D., \& Ikpi, A. (2009). Determinants of Fertiliser Use in Northern Nigeria. Pakistan Journal of Social Sciences 6(2), 91-98.

[20]. Olwande, J., Sikei, G., \& Mathenge, M. (March/April, 2009). Agricultural Technology Adoption: A Panel Analysis of Smallholder Farmers' Fertiliser Use in Kenya. A Paper Presented at the $83^{\text {rd }}$ Annual Conference of the Agricultural Economics Society Dublin.

[21]. Otunaiya, A.O., \& Akinleye, S.O. (2003). Adoption of Improved Maize Production Technologies in Yewa North Local Government Area of Ogun State, Nigeria. A Paper Presented to the Department of Agricultural Economics, Olabisi Onabanjo University, Ogun State.

[22]. Paudel, P., Kumar, A.S., \& Matsuoka, A. (April, 2009). Socio-Economic Factors Influencing Adoption of Fertiliser for Maize Production in Nepal: A Case Study of Chitwan District. A Paper Presented at the $83^{\text {rd }}$ Annual Conference of the Agricultural Economics Society, Dublin. 